\title{
SPECTROFLUORIMETRIC DETERMINATION OF MACROLIDE ANTIBIOTICS USING EOSIN-G DYE
}

Osama H. Abdelmageed ${ }^{1}$, Pakinaz Y. Kashaba ${ }^{2}$ and Ibrahim A. Darwish $^{2}$

${ }^{1}$ Department of Analytical Chemistry, Faculty of Pharmacy, Minia University, Minia, Egypt

${ }^{2}$ Department of Pharmaceutical Analytical Chemistry, Faculty of Pharmacy, Assiut University, Assiut, Egypt

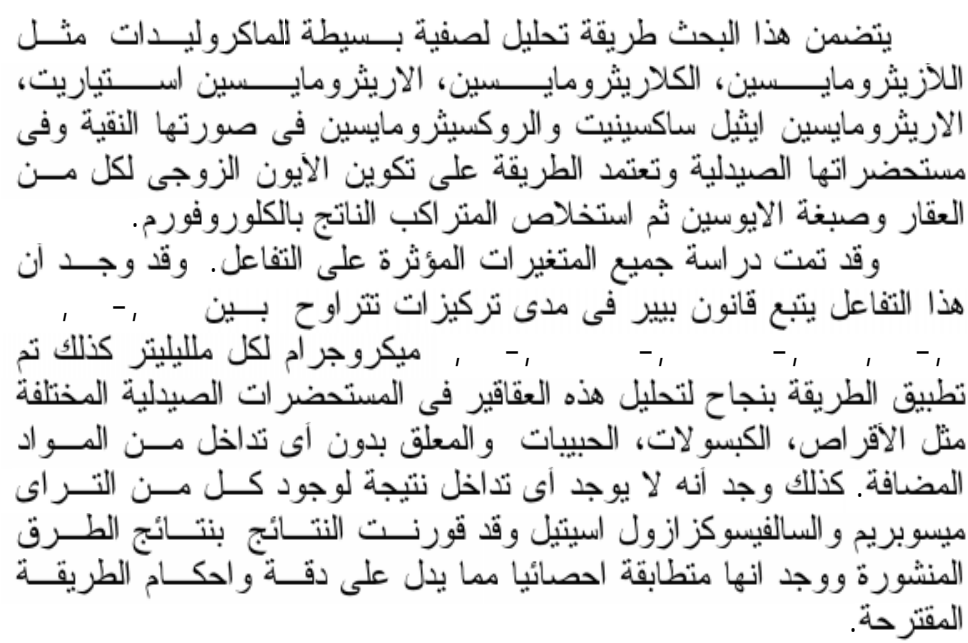

A fully validated and simple spectrofluorimetric method was developed for the determination of azithromycin, clarithromycin, erythromycin ethylsuccinate, erythromycin stearate and roxithromycin in bulk powders and their dosage forms. The proposed method was based on ion pair formation of either one of the cited drugs with eosin- $G$ dye in presence of Mcllvaine buffer and the resultant complex was extracted by chloroform. All variables affecting the intensity of the developed fluorescence products were studied and optimized. Straight line correlation was found over concentration ranges of 0.04-0.2, 0.4-6.4, 4.0-16, 1.612, 0.4-4.0 $\mu \mathrm{g} \mathrm{ml}^{-1}$ for azithromycin, clarithromycin, erythromycin ethylsuccinate, erythromycin stearate and roxithromycin respectively, with good correlation coefficients (0.9973-0.9994).

Received in 4/8/2006 \& Accepted in 21/10/2006 
The limits of detection and quantitation for this method ranged from 0.01 to $1.74 \mu \mathrm{g} \mathrm{ml} l^{-1}$ and from 0.04 to $5.79 \mu \mathrm{g} \mathrm{ml}^{-1}$ respectively. The relative standard deviations were $1.54-2.15 \%$. The proposed method was applied successfully for the determination of the cited drugs in different pharmaceutical dosage forms as tablets, capsules, granules as well as suspension without interference from common encountered additives with overall percentage recoveries ranged from $94.74 \pm 1.17$ to $100.20 \pm 1.57$. In addition no interference was observed due to other active ingredients as trimethoprim and sulfisoxazole acetyl. The results were compared favorably with those of reported method.

\section{INTRODUCTION}

Macrolide antibiotics are produced by Streptomyces species and they are currently used against Gram-positive bacteria. ${ }^{1}$ The macrolide's derivatives studied are: azithromycin (Az), clarithromycin (CL), erythromycin derivatives as erythromycin (ER) ethylsuccinate, erythromycin (ER) stearate and roxithromycin (ROX). These compounds are characterized by the existence of a large lactone ring, thus the name macrolide and a glycosidically linked amino sugar to which is attached dimethylamino on the sugar residue. The structures of this group of drugs are shown in scheme 1 .

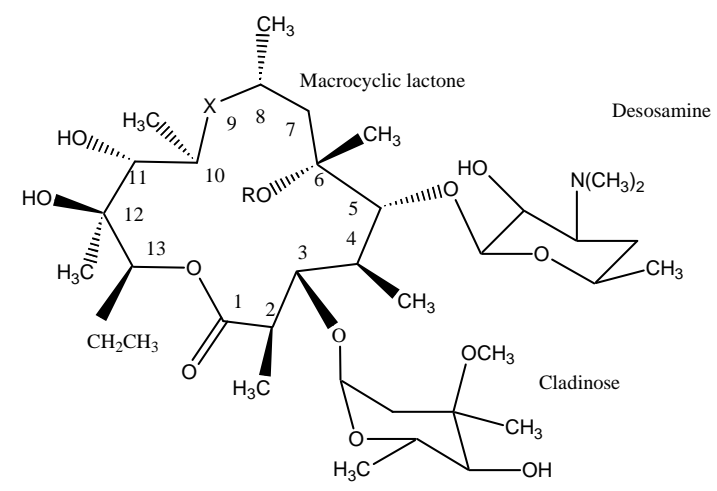

\begin{tabular}{|l|c|c||}
\hline Macrolide & $\mathrm{R}$ & $\mathrm{X}$ \\
\hline Azithromycin* & $\mathrm{H}$ & $\mathrm{N}-\mathrm{CH}_{3}$ \\
\hline Clarithromycin & $\mathrm{CH}_{3}$ & $\mathrm{C}=\mathrm{O}$ \\
\hline Roxithromycin & $\mathrm{H}$ & $\mathrm{C}=\mathrm{N}-\mathrm{OCH}_{2}-\mathrm{OCH}_{2} \mathrm{CH}_{2} \mathrm{OCH}_{3}$ \\
\hline Erythromycin** & $\mathrm{H}$ & $\mathrm{C}=\mathrm{O}$ \\
\hline
\end{tabular}

Scheme I: Structure of the studied macrolide derivatives *as dihydrate ** as ethylsuccinate or stearate 
Several methods have been reported for the determination of these drugs in the literature. These methods are spectrophotometric, ${ }^{2-8}$ spectrofluorimetric, ${ }^{5,9,10-12}$ electrochemical $^{13 \& 14}$ and microbiological. ${ }^{16 \& 17}$ In addition several chromatographic procedures are available such as official methods ${ }^{18-20}$ HPLC, ${ }^{21-25}$ HPTLC, ${ }^{26}$ GC, TLC and capillary electrophoresis. ${ }^{27}$ Ion pair formation provides rapid and convenient methods for the determination of erythromycin, and other macrolide derivatives at low concentrations. Several acid dyes have been used for the spectrophotometric determina-tions of erythromycin such as methyl orange, ${ }^{6}$ orange $\mathrm{IV},{ }^{6}$ bromocresol purple, ${ }^{7}$ bromophenol blue, ${ }^{6}$ bromo-thymol blue, ${ }^{6 \& 8}$ methyl thymol blue and thymol blue. ${ }^{8}$ Roxithromycin has been also determined using wool fast blue, ${ }^{3}$ supracen violet 3B, Tropaeolin $000^{4}$ and bromophenol blue. $^{2}$ Clarithromycin has been also determined using bromophenol blue. ${ }^{2}$ For the time being, no report(s) can be found for the determination of azithromycin through this technique.

There are few literatures available about the spectrofluorimetric analysis of this group of drugs. Naphthotriazole, ${ }^{11}$ erythrosine $\mathrm{B}^{10}$ and tris-(bispyridine) ruthenium $^{12}$ have been reported for the determination of erythromycin and its ester derivatives. All macrolide derivatives have been determined through oxidation with $\mathrm{Ce}^{4+}$ ion $^{9}$ and malonic acid- acetic anhydride. ${ }^{5}$ With the exception of malonic acid-acetic anhydride, no details were given about the possible application of these methods for the determination of some macrolide in presence of some binary antibacterial combination such as erythromycin-trimethoprim, erythromycin-sulfisoxazole acetyl. The voltammetric, chromatographic, and electrophoretic methods always need sophisticated and expensive instruments, in addition to an internal reference secondary standard for chromatographic methods, that may not available in some quality control laboratories. The microbiological methods have many disadvantages such as long incubation periods and lack of sensitivity towards other antibiotics.Therefore, the aim of this work is to develop a new spectrofluorimetric method for routine determination of the mentioned macrolide derivatives in bulk and in different dosage forms available in the local markets, especially in presence of other binary combination such as erythromycin admixture with trimethoprim or sulfisoxazole acetyl. The suggested method depends on the formation of fluorescent ion pair complex between any of the cited drugs and eosin-G dye at $\mathrm{pH} 5-6$, the complex formed can be extracted into chloroform and the fluorescence of the resulting product can be measured at $\lambda_{\text {ex/em }} 480 \pm 2 / 551 \pm 1 \quad \mathrm{~nm}$. This reaction was successfully carried out for all the studied drugs due to their basic characters (their pka values are between 6.0 and 9.0). ${ }^{1}$ 


\section{EXPERIMENTAL}

\section{Apparatus}

Spectrofluorimeter: Perkin-Elmer LS 45 (Perkin-Elmer, Inc., UK) with FL WINLAB software. The excitation and emission band widths were both $10 \mathrm{~nm}$ and standard $1 \mathrm{~cm}$ quartz cell was used for recording the spectra and carrying out fluorescence measurements.

- Spectrofluorimeter: Shimadzu, RFI-5301 PC, Kyoto, Japan. The excitation and emission band widths were both set at $10 \mathrm{~nm}$ and standard $1 \mathrm{~cm}$ quartz cell was used.

- Micro-computer pH meter model 6209 (Jenco electronics, LTD, U.S.A.).

- Centrifuge (Fisher Scientific, USA).

- Bran sonic (Bender \& Hobein, Zunch, Switzerland)

- Thermostatically controlled water bath (Büchi, Glasapparatefabrik Flawil, Switzerland).

- Analytical Balance (Mettler Toledo, Switzerland)

\section{Chemicals and reagents}

Analytical grade chemicals and doubly distilled water were used throughout all the work. Azithromycin (98.7\%), clarithromycin (98.9\%), erythromycin ethylsuccinate (USP sample) and erythromycin stearate (USP sample) were obtained from Abbot laboratories (North Chicago, IL, USA). Roxithromycin (99.0\%) was obtained from T3A Pharma Group (Assiut, Egypt). Trimethroprim
(99.2\%) was obtained from Welcome Foundation; LTD; London. Sulfisoxazole acetyl $(98.0 \%)$ was obtained from Medical Union Pharmaceuticals (Abu Sultan-Ismailia-Egypt, under license from Abbott Laboratories USA). Purities of all these drugs and compliance with the pharmaceutical requirements were confirmed by their local companies and were used as authentic samples.

- Eosin-G reagent $\left(\mathrm{C}_{20} \mathrm{H}_{6} \mathrm{Br}_{4} \mathrm{Na}_{2} \mathrm{O}_{5}\right)$, $2^{\prime}, 4^{\prime}, 5^{\prime}, 7^{\prime}$-Tetrabromo-3', $6^{\prime}$-dihydroxyspiro[isobenzofuran-1(3H), $9^{\prime}$ [9H] xanthen]-3-one disodium salt; M.Wt 691.85 , yellow shade; $2.89 \mathrm{x}$ $10^{-3} \mathrm{M}$; was prepared by dissolving $0.2 \mathrm{gm}$ of eosin-G (s.d.fine-chem. Ltd, Boisar, India) in $10 \mathrm{ml}$ double distilled water and the resultant solution was made up to $100 \mathrm{ml}$ with double distilled water.

- Mcllvaine buffer solution; ${ }^{28} \mathrm{pH}$ ranges from 2.2-8; were prepared using $0.2 \mathrm{M}$ disodium hydrogen phosphate and $0.1 \mathrm{M}$ citric acid both prepared in freshly boiled and cooled double distilled water.

\section{Pharmaceutical formulations}

The following pharmaceutical preparations were purchased from the local market and used in the present study: Xithrone ${ }^{\mathrm{TM}}$ tablets (Amoun Pharmaceutical Co. El-Obour City, Cairo, Egypt) labeled to contain 500 $\mathrm{mg}$ of azithromycin per tablet. Xithrone $^{\mathrm{TM}}$ oral suspension (Amoun Pharmaceutical Co. El-Obour City, Cairo, Egypt) labeled to contain 200 $\mathrm{mg}$ of azithromycin for each $5 \mathrm{ml}$. Klacid $^{\mathrm{TM}}$ tablets (GlaxoWellcome, 
El-Salam City, Cairo, Egypt, under license of Abbot laboratories international) labeled to contain 250 $\mathrm{mg}$ of clarithromycin per tablet. Erythrocin $^{\text {TM }}$ tablets (Kahira Pharm. \& Chem. Ind. Co., under license from Abbott laboratories) labeled to contain erythromycin stearate equivalent to $500 \mathrm{mg}$ erythromycin base per tablets. Erythroprim ${ }^{\mathrm{TM}}$ tablets (Misr Co for Pharmaceutical Industries, Cairo, Egypt) labeled to contain erythromycin stearate equivalent to $250 \mathrm{mg}$ of erythromycin base and $80 \mathrm{mg}$ of trimethoprim per tablet. Primomycin ${ }^{\mathrm{TM}}$ capsules (Rameda Co for Pharmaceutical Industries \& Diagnostic Reagents, $6^{\text {th }}$ October City, Egypt) labeled to contain $400 \mathrm{mg}$ of erythromycin as ethylsuccinate and $100 \mathrm{mg}$ of trimethoprim per capsule. Primomycin $^{\mathrm{TM}}$ oral Suspension (Rameda Co for Pharmaceutical Industries \& Diagnostic Reagents, $6^{\text {th }}$ October city, Egypt) labeled to contain $200 \mathrm{mg}$ of erythromycin as ethylsuccinate and 50 $\mathrm{mg}$ of trimethoprim for each teaspoonful.

Erythrocin $^{\mathrm{TM}}$ granules (Kahira Pharm. \& Chem. Ind. Co. Egypt, under license of Abbot laboratories, North Chicago, IL, USA) labeled to contain erythromycin ethylsuccinate equivalent to erythromycin base 200 mg per teaspoonful. Roxid ${ }^{\mathrm{TM}}$ tablets (T3A, Assiut, Egypt) labeled to contain $300 \mathrm{mg}$ of roxithromycin per tablet.
Preparation of standard solutions and calibration curve

A stock solution of the studied macrolide, except erythromycin ethylsuccinate, was prepared in absolute ethanol in order to obtain $1 \mathrm{mg} \mathrm{ml}^{-1}$. For erythromycin ethylsuccinate a stock solution was prepared in the same solvent in order to obtain $5 \mathrm{mg} \mathrm{ml}^{-1}$ then diluted quantitatively with doubled distilled water and absolute ethanol to obtain $10 \% \mathrm{vv}^{-1}$ ethanol: water so as to obtain a working standard solution of 100$400 \mu \mathrm{g} \mathrm{ml}^{-1}$. Stock solutions of other studied antibiotics were quantitatively diluted with the same solvent so as to obtain working standard solutions of $1-5,10-160,40-300$, and 10-100 $\mu \mathrm{g}$ $\mathrm{ml}^{-1}$ for azithromycin, clarithromycin, erythromycin stearate, and roxithromycin respectively.

Preparation of sample solutions containing single drug preparation 1- Tablets

Twenty tablets of each of xithrone, klacid, erythrocin, and roxid were weighed and finely powdered. An amount of the powdered tablets equivalent to $50 \mathrm{mg}$ of the cited drug was transferred into $50 \mathrm{ml}$ volumetric flask followed by $20 \mathrm{ml}$ absolute ethanol and the mixture was shaken well for about $5 \mathrm{~min}$. The resultant mixture was completed to volume with the same solvent. The mixture was mixed well, allowed any insoluble matter to settle down, and then filtered. The first portion of the filtrate was rejected and an accurate measured volume of the filtrate was diluted quantitatively with absolute 
ethanol to obtain concentrations within calibration ranges, and then subjected to analysis as described under general procedure.

\section{2- Granules for oral suspension}

Xithrone- An amount of dry finally powdered mixture of xithrone oral suspension, accurately weighed, equivalent to $50 \mathrm{mg}$ azithromycin was subjected to the same procedure described under tablet formulation containing single preparation.

Erythrocin granules was prepared as prescribed $(200 \mathrm{mg}$ base per $5 \mathrm{ml}$ double distilled water), mixed well, and sonicated for about $10 \mathrm{~min}$ to ensure homogenization of the resultant mixture. Then $5 \mathrm{ml}$ of the freshly prepared, mixed and oral bubbles free oral suspension were accurately transferred to a $50 \mathrm{ml}$ volumetric flask, followed by $25 \mathrm{ml}$ absolute ethanol. The resultant mixture was shaken for about $5 \mathrm{~min}$, completed to volume with the same solvent and filtered. The first portion of the filtrate was rejected and an accurate measured volume of the filtrate was diluted quantitatively with doubled distilled water and absolute ethanol to obtain sample concentrations in $10 \%$ ethanol: water as final solvent. Sample solutions were subjected to analysis as described under general procedure.

\section{Preparation of sample solutions containing binary drug combination \\ 1- Erythroprim tablets}

Twenty tablets were weighed and finely powdered. An amount of powdered tablets equivalent to $50 \mathrm{mg}$ of erythromycin stearate was shaken with about $10 \mathrm{ml}$ of diethyl ether for about $5 \mathrm{~min}$ each. The resultant mixture was centrifuged for about 5 $\mathrm{min}$ at $3500 \mathrm{rpm}$. The ether extract was drained carefully into dry beaker and the same step is repeated twice. The combined ether extracts were evaporated to dryness in water bath at $40^{\circ}$. The residue left was transferred quantitatively with absolute ethanol into $50 \mathrm{ml}$ volumetric flask and completed to volume with the same solvent. The resulting solution was subjected to analysis as explained under the general procedure.

\section{2- Primomycin capsules}

The contents of 10 capsules were weighed, mixed well and finely powdered if necessary. An accurately weighed amount of the powdered mixture equivalent to $50 \mathrm{mg}$ erythromycin ethylsuccinate was subjected to analysis as described under the analysis of erythroprim tablet.

\section{3- Primomycin oral suspension}

An amount of dry powdered mixture of oral suspension equivalent to 50 mg erythromycin ethylsuccinate was subjected to the same procedure described for the analysis of erythroprim tablet.

\section{Recovery experiments}

An accurately weighed amount of each of the studied standard macrolide antibiotics (25 $\mathrm{mg})$ drug was added to an accurately weighed quantity (equuvalent to $25 \mathrm{mg}$ ) of its corresponding formulation, and then 
procedure was continued as mentioned under the analysis of their corresponding dosage forms. The difference in fluorescence intensity between analytical results for the samples with and without the added standard drug was used to calculate amount of added drug.

\section{General procedure}

One milliliter of the working standard solution or sample preparation of the cited drugs was transferred quantitatively into separatory funnel containing the specified volume of buffer and dye solution as mentioned in Table 1 . The mixture was mixed well and diluted with double distilled water to about $10 \mathrm{ml}$. The resulting solution was extracted by 3 x 8 portion of chloroform for about one min each time. The resulting extracts were combined into dry $25 \mathrm{ml}$ volumetric flask and completed to volume with the same solvent. The content of the flask was then treated with small amount of chloroform washed anhydrous sodium sulfate and shacked well for about $1 \mathrm{~min}$. After all the solid sodium sulfate was settled down, the emission of each of the clear final diluted solution (0.04$0.2,0.4-6.4,4-16,1.6-12$, and 0.4 $4.0 \mu \mathrm{g} \mathrm{ml}^{-1}$ azithromycin, clarithromycin, erythromycin ethylsuccinate, erythromycin stearate, and roxithromycin respectively) was measured, within 10 min, against a reagent blank treated similarly at the specified $\lambda_{\mathrm{ex} / \mathrm{em}}$ (Table 1).

Table 1: The specific parameters used for determination of each studied macrolide according to the general procedure.

\begin{tabular}{|l|c|c|c|c|}
\hline Macrolide & $\mathrm{pH}$ & $\begin{array}{c}\text { Buffer's Vol. } \\
\mathrm{ml}\end{array}$ & $\begin{array}{c}\text { Dye's Vol. } \\
\mathrm{ml}\end{array}$ & $\lambda_{\text {ex/em }}$ \\
\hline Azithromycin & 6 & 6 & 3 & $480 / 550$ \\
Clarithromycin & 5 & 2 & 2 & $478 / 552$ \\
Erythromycin & 6 & 2 & 3 & $481 / 552$ \\
ethylsuccinate & - & - & - & \\
Erythromycin & 6 & 2 & 2 & $482 / 552$ \\
Stearate & - & - & - & \\
Roxithromycin & 5 & 2.5 & 2 & $478 / 552$ \\
\hline
\end{tabular}




\section{Stoichiometric relationship}

Job's method of continuous variation $^{29}$ was applied. Equimolar solutions of eosin-G, in double distilled water, and each drug in absolute ethanol were prepared. With the exception of azithromycin, $2.89 \mathrm{x}$ $10^{-3} \mathrm{M}$ solution was prepared for both dye and the rest of drugs, while 2.89 x $10^{-4} \mathrm{M}$ solution for both dye and azithromycin were used throughout the study. A series of $1 \mathrm{ml}$ portions of the solutions in different complementary proportions (from 1.0: 0.0 to 0.0 : 1.0 ; drug: reagent inclusive) were prepared and transferred quantitatively to a separatory funnel containing the specified volume of buffer recommended for each drug and diluted to about $10 \mathrm{ml}$ with distilled water. The procedure was continued as described under the general procedure starting from "The resulting solution was extracted with $3 \times 8$ portion of chloroform......".

For azithromycin the molar ratio was further confirmed through MoleRatio Method. ${ }^{29}$ An aliquot of azithromycin solution $(0.5 \mathrm{ml}$ of 2.89 x $10^{-4} \mathrm{M}_{\text {) }}$ were treated, separately, with $0.5,1,1.5$ and $2 \mathrm{ml}$ of eosin dye solution $\left(2.89 \times 10^{-4} \mathrm{M}\right)$, then the specified volume of buffer recommended for azithromycin was added. After completion to about 10 $\mathrm{ml}$ with doubled distilled water, the complex formed was extracted and analyzed as explained under the general procedure starting from "The resulting solution was extracted with $3 \times 8$ portion of chloroform .......".

\section{RESULTS AND DISCUSSION}

All macrolide antibiotics contain tertiary amine in the desosamine moiety. Azithromycin contains another additional tertiary amine instead of the carbonyl group that exists in the backbone structure of other drugs; clarithromycin and erythromycin; (scheme 1). Thus cited drugs can be readily protonated. Fluorescein and its derivatives have been used as ion pairing agents for the extraction - spectrophotometric and extraction - spectrofluorimetric determination of metal ions. ${ }^{30 \& 31}$ Therefore the formation of associates ion pair(s) between macrolides antibiotics and fluorescein dye's derivative is of potential application in the spectrofluorimetric determination of these antibiotics. Our attention was focused on eosin dye owing to the fact that it gave best fluorescence signal relative to all other fluorescein dyes, ${ }^{30 \& 31}$ commercially available at lower cost and can be easily synthesized through bromination of fluorescein.

According to the following scheme (Scheme 2) macrolide antibiotics (I) combines with the anion of eosin dye (II) and then transferred from the aqueous phase into organic phase in the form of an ion pair (III): 




(I) (aq.)



(III) (aq.)

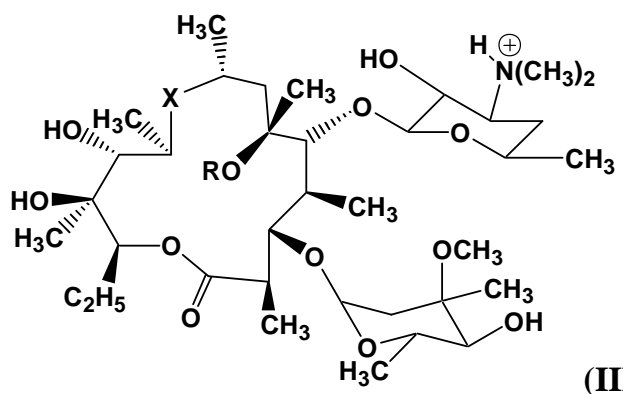

(III) (org)<smiles>O=C([O-])c1ccccc1-c1c2cc(Br)c(=O)c(Br)c-2oc2c(Br)c(O[N+](=O)[O-])c(Br)cc12</smiles>

(II) (aq.)<smiles>O=C([O-])c1ccccc1-c1c2cc(Br)c(=O)c(Br)c-2oc2c(Br)c(O[O-])c(Br)cc12</smiles><smiles>O=C([O-])c1ccccc1-c1c2cc(Br)c(=O)c(Br)c-2oc2c(Br)c(O[O-])c(Br)cc12</smiles>

Scheme 2: Proposed mechanism for ion pair association between the studied macrolide derivatives and eosin-G dye.

( $\mathrm{n}=1$ for all studied macrolides, except $\mathrm{n}=2$ in case of azithromycin where $\mathrm{X}=\mathrm{NCH}_{3}$ ) 


\section{Preliminary investigations}

The effect of the extracting solvent was examined through preliminary investigations because the polarity of a solvent affects both extraction and fluorescence intensity. Thus several halogenated and non halogenated solvents were examined as solvents for extraction of ion - pair with eosin such as chloroform, 1, 1dichloromethane, 1, 2- dichloroethane, carbon tetrachloride, toluene, benzene and cyclohexane. With all the studied macrolides, dissolved in ethanol, best results were observed with chloroform, followed by 1,2 dichloroetane, then 1, 1-dichloromethane. With other solvents used no difference could be detected between blank and experiment. Therefore chloroform was used for consequent experiments.

Preliminary experiments were also carried out to determine the right strength of ethanol used as a solvent for the studied drugs. With the exception of erythromycin ethylsuccinate, best results were observed using absolute ethanol, rather than ethanol - water mixture in different proportions. However, with erythromycin ethylsuccinate best results were obtained upon using $10 \% \quad \mathrm{v} \mathrm{v}^{-1}$ ethanol: water rather than any higher $\%$ ethanol in water or even absolute ethanol as solvent. This can be accounted on the poor solubility of these drugs, except erythromycin ethylsuccinate, in different proportions of ethanol: water mixture. With all the studied drugs, although the fluorescence intensity of the analyte and the reagent blank increased with increased percentages of ethanol in the aqueous phase before extraction, however the difference between them diminished. Therefore it was found that better results can be obtained upon keeping the total volume of the aqueous layer about $10 \mathrm{ml}$, thus the maximum percentage of ethanolwater was about $10 \% \mathrm{v} \mathrm{v}^{-1}$ for the studied macrolides except for erythromycin was only about $1 \% \mathrm{v} \mathrm{v}^{-1}$.

\section{Excitation and fluorescence spectra}

Both eosin-G and its ion associates have almost identical excitation and emission wavelengths. Thus they must be separated if the ion pair is to be quantified. Figure 1 shows both excitation and emission spectra of the complex extracted by following the suggested general procedure. With all the compounds studied, the excitation spectra have three maxima at about $480 \pm 2 \mathrm{~nm}$, $505 \pm 1 \mathrm{~nm}$ and $540 \pm 1 \mathrm{~nm}$. However the emission peak at either one of the mentioned $\lambda_{\text {ex }}$ appears at about 550 . Excitation at $480 \pm 2 \mathrm{~nm}$ was chosen not only due to better stoke shift with the wavelength of emission but also due to better resolution observed between the emission peak of the product and another peak confirmed to be due to Raman scattered light by the ultra-traces of water remained in chloroform extract. In case of $\lambda_{\mathrm{ex}}$ at about $505 \mathrm{~nm}$ the Raman scattered peak was red shifted and partially overlapped with the emission peak. In case of $\lambda_{\mathrm{ex}}$ at $540 \mathrm{~nm}$ the Raman scattered and emission peaks are 
completely overlapped in one broad peak, thus no way to distinguish the emission peak under this condition.

\section{Optimization of reaction parameters}

In order to establish the optimum $\mathrm{pH}$, volume of buffer and dye recommended for maximum fluorescence intensity a series of experiments were conducted using fixed amount of drug and varying the parameter to be studied, then the general suggested procedure was followed. All studies are done at room temperature, about $25^{\circ}$.

\section{1- Effect of pH}

The effect of $\mathrm{pH}$ of the aqueous phase on ion pair extraction was studied using Mcllvaine buffer solution over a $\mathrm{pH}$ range of $2.2-8$ (Figure 2). It was clear that at $\mathrm{pH}<4$ no significance differences could be obtained between the fluorescence intensity of both blank and experiments. The fluorescence intensity of the chloroform extract reached a maximum at $\mathrm{pH} 6$ for azithromycin, erythromycin ethylsuccinate and erythromycin stearate, and at $\mathrm{pH} 5$ for clarithromycin and roxithromycin. These data were chosen for subsequent investigation.

\section{2- Effect of buffer's volume}

The effect of buffer's volume at the chosen $\mathrm{pH}$ on ion pair extraction was also studied (Figure 3). Maximum fluorescence intensities were obtained at $6 \mathrm{ml}$ for azithromycin, and $2 \mathrm{ml}$ for clarithromycin, erythromycin ethylsuccinate, erythro- mycin stearate. and $2.5 \mathrm{ml}$ for roxithromycin. Accordingly buffer's volume listed in the experimental section were chosen and used for subsequent investigation.

\section{3- Effect of dye's volume}

Under the established experimental conditions regarding $\mathrm{pH}$ and buffer's volume, the effect of dye's volume on the extraction of ion pair complex was also studied (Figure 4). Maximum fluorescence intensities were obtained upon using $2 \mathrm{ml}$ of eosin for clarithromycin, erythromycin stearate and roxithromycin and $3 \mathrm{ml}$ for azithromycin and erythromycin ethylsuccinate. Although the fluorescence intensity of the complex formed and the reagent blank increased with increased volume of dye, over $3 \mathrm{ml}$, however the difference between them diminished dramatically. Thus the volumes of dye reported in the experimental section under general procedure, were chosen for subsequent investigation.

\section{4- Rate of extraction, efficiency of extraction and stability of the extracts}

Shaking times ranging from 0.5 to $2 \mathrm{~min}$ did not produce any change in the fluorescence intensities, thus 1 min shaking time was selected. Reproducible fluorescence readings were obtained after successive 3 extraction steps each with about $8 \mathrm{ml}$ of chloroform. The fluorescence of the chloroform extracts remained constant for about $20 \mathrm{~min}$ with 
azithromycin, $15 \mathrm{~min}$ for clarithromycin, and 10 min with erythromycin ethylsuccinate erythromycin stearate, and roxithromycin. After about $4 \mathrm{hrs}$, the fluorescence intensities dropped down to about $65-75 \%$ relative to their starting values with all compounds, except for roxithromycin dropped down dramatically to about $5 \%$ of its starting values. Therefore the fluorescence intensities, for both blank and experiments must be measured within maximum $10 \mathrm{~min}$ after extraction.

\section{Stoichiometric relationship}

Job's method of continuous variation (29) was used to study the molar ratios of the formed complex. With the exception of azithromycin, the methods revealed a 1: 1 ratio for the rest of the studied macrolide derivatives: eosin dye respectively (Figure 5a). For azithromycin a 1:2 ratio for drug: dye respectively was observed and this is in agreement with the presence of additional tertiary nitrogen atom in the backbone structure of the macrolide ring. For azithromycin the molar ratio was further confirmed by mole-ratio method (29) and was also found to be 1:2 drug : eosin dye respectively (Figure $5 b$ ). The stability constants of the formed complexes were calculated according to the following equation:

$$
K=\frac{R F l / R F l_{e x} C_{x}}{\left(C_{M}-R F l / R F l_{e x} C_{X}\right)\left(C_{L}-n R F l / R F l_{e x}\right)^{n}}
$$

where $\mathrm{K}$ is the stability constant of the formed complex. $M$ indicates drug, $L$ indicates eosin dye, $n=x /$ ( 1 $\mathrm{x})$ where $\mathrm{x}$ is the mole fraction of the dye at the maximum of the continuous variation curve. RFI/ $\mathrm{RFI}_{\text {ex }}$ is the ratio of the observed relative fluorescence intensity to that indicated by the tangent for the same wavelength. $C_{M}$ and $C_{L}$ are the concentration of the drug and eosin dye respectively, $C_{x}=C_{L} / n{ }^{32}$

The calculated stability constants $(\log \mathrm{K})$ for the formed complexes (Table 2) are ranged from 5.94 to 9.10 indicating, in general, good stability of the formed complexes. Results obtained are in good agreement with the stability studies, where azithromycin represents the most stable complex indicated by its higher $\log \mathrm{k}$ value. In addition roxithromycin, which represents the least stable complex over the total time of study has the least $\log \mathrm{K}$ value. 


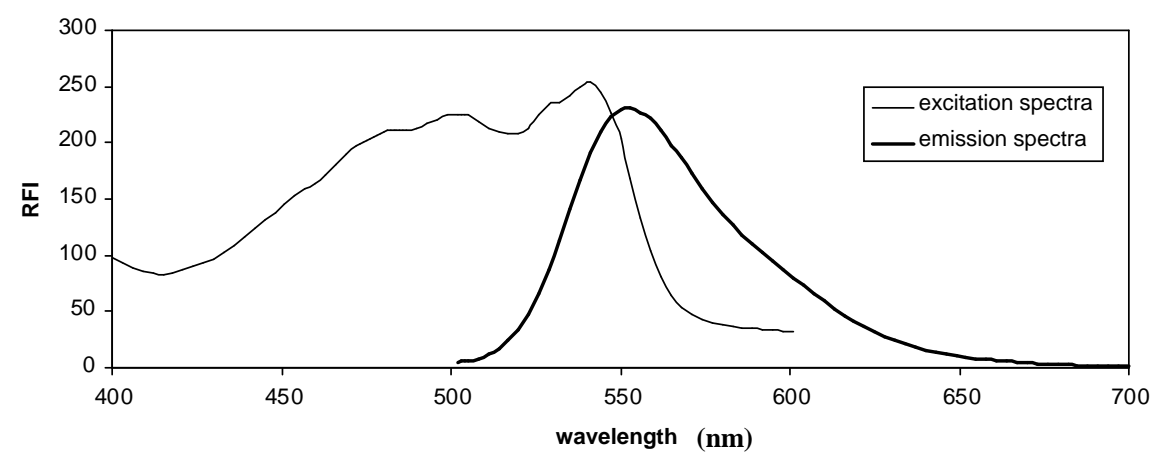

Fig. 1 : Excitation and emission spectra of erythromycin stearate- eosin complex product Final concentration: $12 \mathrm{~g} \mathrm{ml}^{-1}$

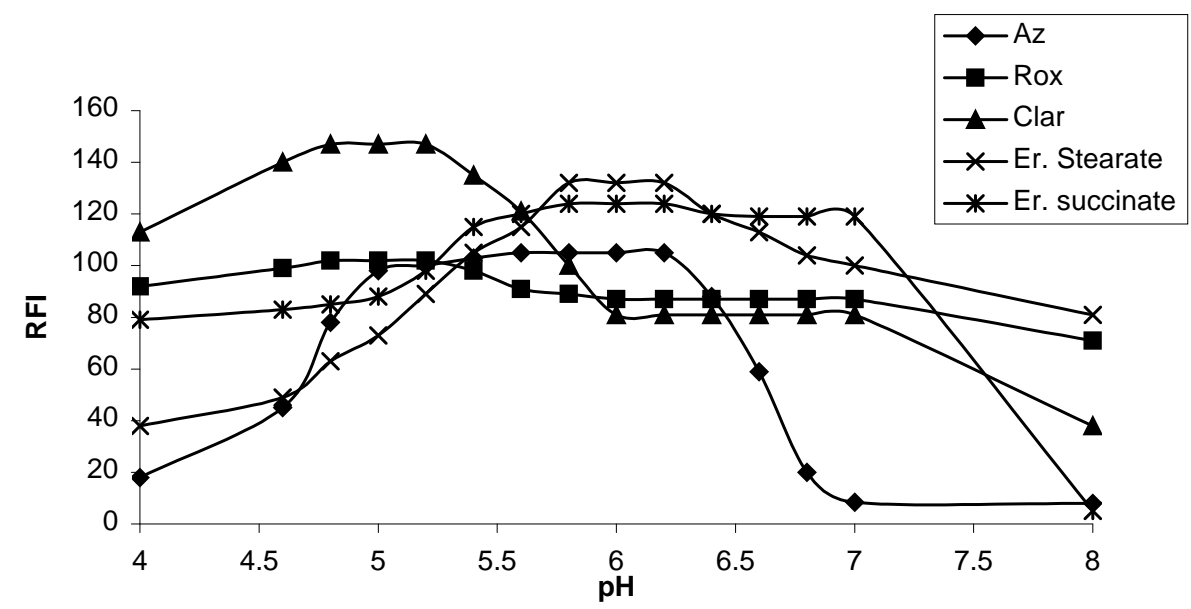

Fig. 2: Effect of $\mathrm{pH}$ on the fluorescence intensities of drug : dye complexes for the studied drugs. (Final concentration in $\mu \mathrm{g} \mathrm{ml}{ }^{-1}: \mathrm{Az} \mathrm{0.12;} \mathrm{Clar} \mathrm{4;}$ Er.stearate 6.4; Er succinate 8; Rox 2 ) 


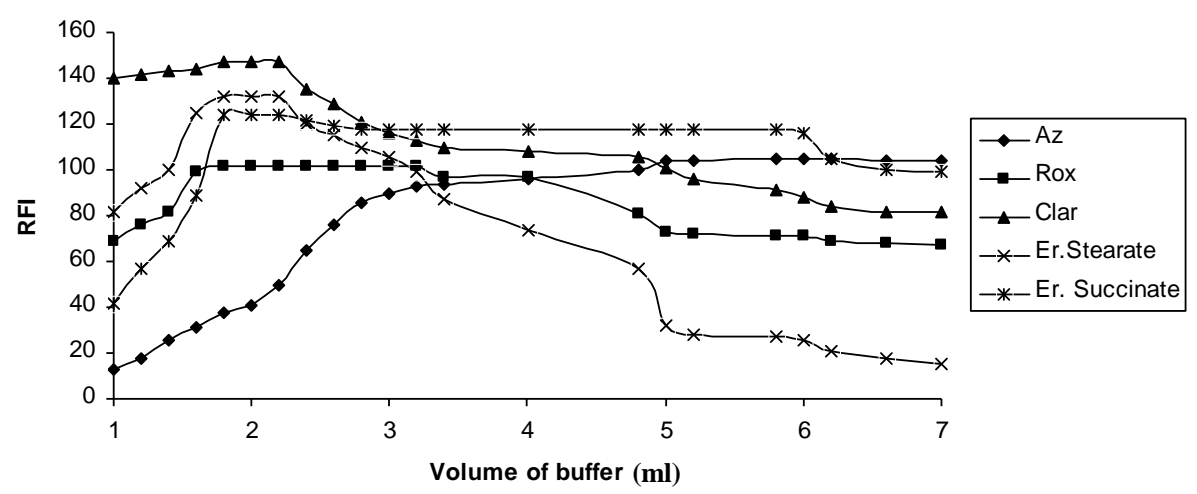

Fig. 3: Effect of volume of buffer on the fluorescence intensities of drug : dye complexes for the studied drugs.

(Final concentration in $\mathrm{g} \mathrm{ml}^{-1}$ : Az 0.12; Clar 4; Er.stearate 6.4; Er succinate 8; Rox 2 )

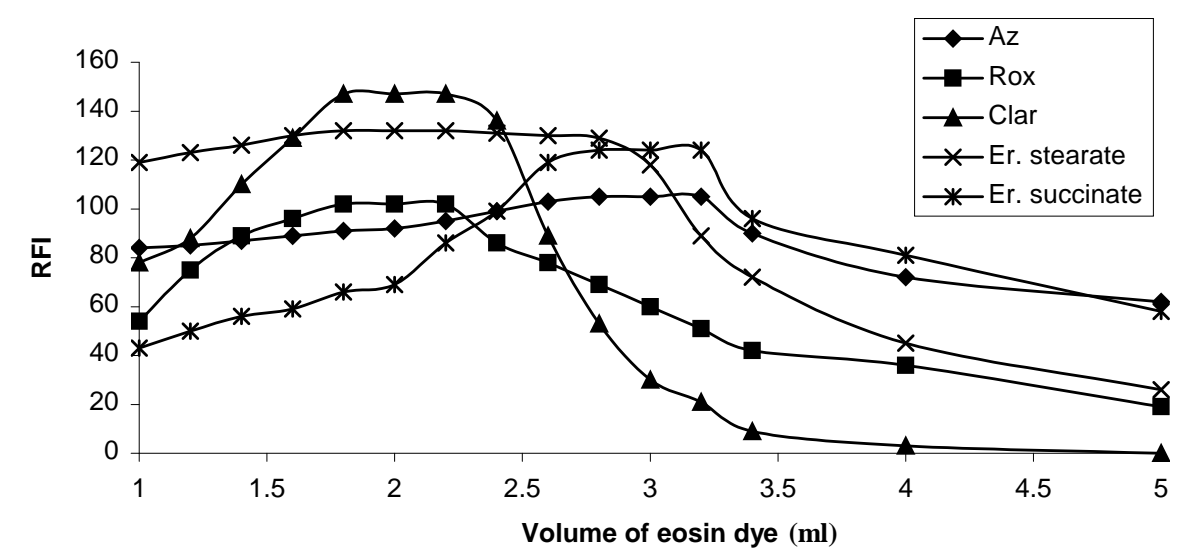

Fig. 4: Effect of volume of dye on the fluorescence intensities of drug : dye complexes for the studied drugs.

(Final concentration in $\mathrm{g} \mathrm{ml}^{-1}: \mathrm{Az} \mathrm{0.12}$; Clar 4; Er.stearate 6.4; Er succinate $8 ; \operatorname{Rox} 2$ ) 


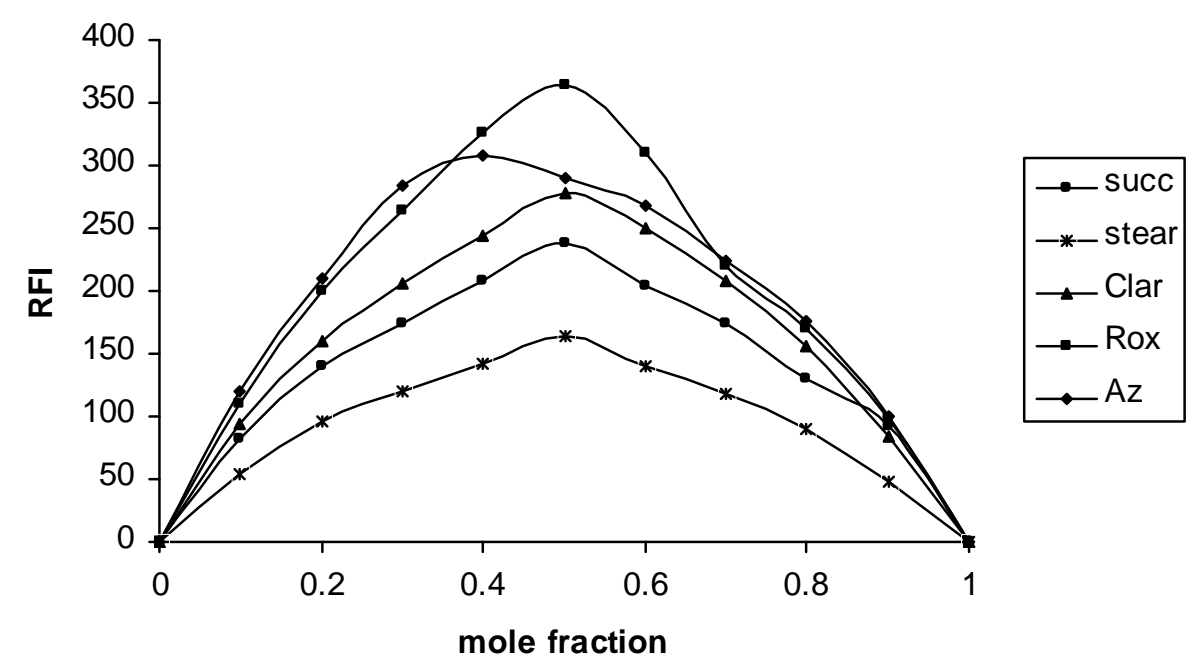

Fig. 5a: Molar ratios of the studied drugs-dye complexes through Job's method of continuous variation

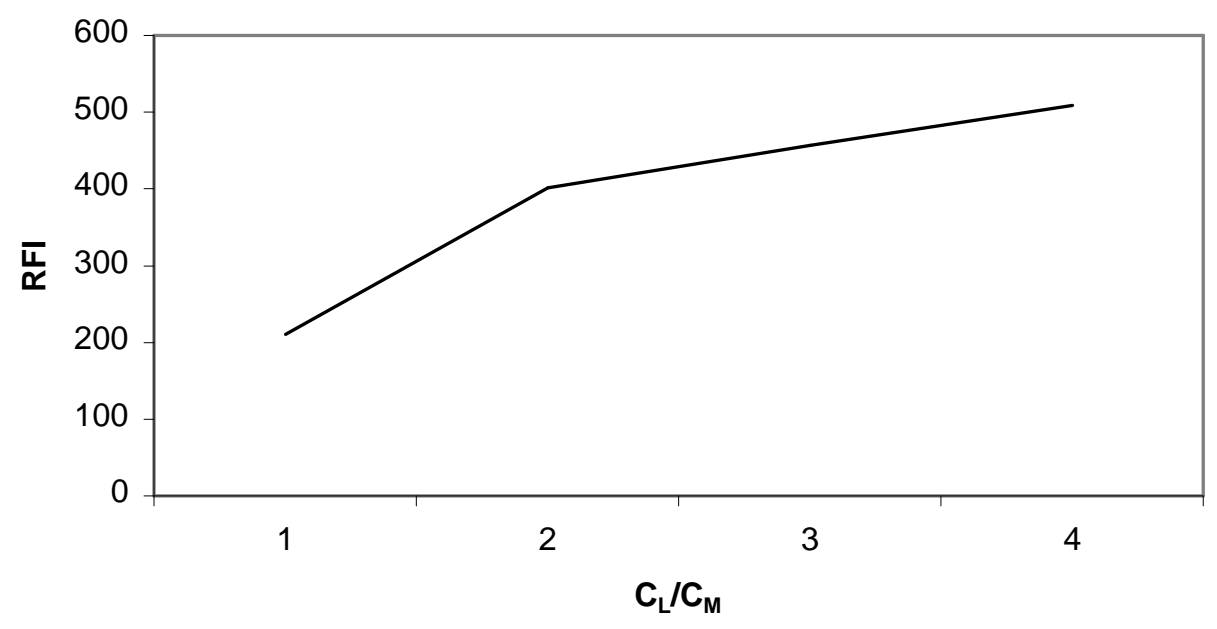

Fig. 5b: Molar ratio of azithromycin-dye complex through mole-ratio method, $\left(C_{L}\right.$ is the molar concentration of eosin dye and $C_{M}$ is the molar Concentration of AZ). 
Validation of the proposed method $^{18}$

\section{1- Linearity, detection and quantitation limits}

Under the optimized reaction conditions, the calibration curves for the investigated drugs with the target reagent used in this work were constructed by analyzing a series of the standard solutions of the drugs. The assay was performed according to the general suggested analytical procedure previously described under the experimental section. The regression equations for the results were derived by using the least squares method (Table 3 ). In all cases RFI $(n=3)$ were linear with good correlation coefficients in the general concen-tration range of $0.04-16 \mu \mathrm{g}$ $\mathrm{ml}^{-1}$. The limits of detection (LOD) and limits of quantitation (LOQ) were determined using the following equation: ${ }^{33}$

$$
\mathrm{LOD} \text { or } \mathrm{LOQ}=\mathrm{k} \mathrm{SD} / \mathrm{b}
$$

where $\mathrm{k}=3$ for LOD and 10 for LOQ. $\mathrm{SD}_{\mathrm{a}}$ is the standard deviation of the intercept, and b is the slope. On the basis of 3 replicate measurements the LOD and LOQ values were $0.01-1.74$ and 0.04-5.79 $\mu \mathrm{g} \mathrm{ml}^{-1}$ respectively. Azithromycin gave relatively the highest sensitivity, followed by roxithromycin, then clarithromycin and finally erythromycin derivatives. The reason of such higher observed sensitivity with azithromycin can be accounted on the existence of other tertiary nitrogen atom in the macrolide's backbone structure. Since it is less sterically hindered, this tertiary nitrogen atom is expected to form a unique stable complex with the studied dye under the chosen experimental condition. This is proved by the much higher sensitivity and better stability observed with azithromycin compared to other studied drugs (Table 2). Data of such analysis are summarized in Table 3.

\section{2- Repeatability}

The precision of the proposed method was checked by replicate analysis for six separate samples solution of each of the cited drugs. The relative standard deviations (RSD) were 1.95, 1.73, 1.88, 1.27 and 1.75 for a concen-tration of $0.12 \mathrm{~g}$ $\mathrm{ml}^{-1}$ azithromycin, $4 \quad \mu \mathrm{g} \quad \mathrm{ml}^{-1}$

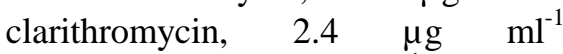
roxithromycin, $8 \mu \mathrm{g} \mathrm{ml}{ }^{-1}$ erythromycin ethylsuccinate and $6 \mu \mathrm{g} \mathrm{ml}^{-1}$ erythromycin stearate respectively. The bias values (\% deviation from the regression line values) were $\leq-0.97$. These levels of precision and accuracy of the proposed method was adequate for routine analysis of any of the cited drugs in their pharmaceutical dosage forms.

\section{3- Interference studies}

Regarding the possible interference that may exist due to the presence of some drugs in certain binary combination with either erythromycin ethylsuccinate or erythromycin stearate such as trimethoprim or sulfisoxazole acetyl respectively. Those active ingredients are tested separately by the suggested procedure. Trimethoprim was studied over a concentration range of $0.1-4$ $\mu \mathrm{g} \mathrm{ml}^{-1}$, while sulfisoxazole acetyl 
was studied over concentration range of $10-60 \mu \mathrm{g} \mathrm{ml}^{-1}$, both calculated based on the ratio allowed with erythromycin derivatives in the commercially available dosage form. The results of such studies indicated that trimethoprim showed highly interference at concentration above $0.2 \mu \mathrm{g} \mathrm{ml}^{-1}$, while sulfisoxazole acetyl did not. The interference of trimethoprim may be accounted on the presence of free amino groups in its structure and its reported $\mathrm{pK}_{\mathrm{a}}$ value $6.6,{ }^{34}$ while negative interference of sulfisoxazole acetyl can be accounted on its acidic character. ${ }^{35}$ Thus sulfisoxazole acetyl can be considered to be acidic compounds relative to trimethoprim and it is too difficult to form a cationic form at the chosen $\mathrm{pH}$. In order to eliminate the interference due to trimethoprim, its solubilities in different solvents has been checked, ${ }^{34}$ trimethoprim was found to be practically insoluble in diethyl ether. while both erythromycin stearate and the succinate derivatives were found to be practically soluble. ${ }^{1}$ Thus diethyl ether was chosen as a solvent for extraction of erythromycin derivatives from their dosage forms containing in addition trimethoprim. Analysis of laboratory prepared mixtures of erythromycin ethylsuccinate and sulfisoxazole acetyl in different proportions (Table 4) by the proposed method indicate the accuracy as well as the precision of the suggested procedure for the analysis of erythromycin ethylsuccinate in presence of sulfisoxzaole acetyl.

\section{4- Accuracy and recovery}

The accuracy of the proposed method was validated and judged by the analysis of pharmaceutical dosage forms as tablets, capsules and oral suspension dosage forms by both suggested and proposed methods. ${ }^{5}$ According to the $\mathrm{F}$ - and $\mathrm{t}-$ test there is no significant difference between both proposed and reported methods. The accuracy of the current method was also confirmed through recovery studies using standard addition method. Results obtained indicate good recoveries which reflect selectivity of the extraction procedures, using absolute ethanol with single drug preparation or selective extraction by diethyl ether for either erythromycin ethylsuccinate or stearate in presence of trimethoprim. Thus no interference could be expected from frequently encountered common excipients, additives, and other active ingredients. Therefore the proposed method can be considered as a specific method for determination of the cited drugs in commercially available dosage forms (Table 5).

\section{5- Robustness and ruggedness}

A study of small variation of some of the operational conditions; such as $\mathrm{pH}$, volumes of dye and/or buffer; on the recoveries and standard deviations of bulk drugs was carried out. As shown in Table 6, results obtained were not significantly affected within the studied ranges of variations in the assay conditions, thus the proposed procedure can be considered robust. The ruggedness of the suggested 
procedure was also examined in different laboratories at varying time, analyst and two different instruments (listed in the experimental section). The results obtained were found to be reproducible, since no significant difference were observed in the recoveries or standard deviation values.

Table 2: Stability constant of the studied complexes

\begin{tabular}{||l|c|}
\hline Drug & Log K \\
\hline Azithromycin & 9.1 \\
Clarithromycin & 6.4 \\
Erythromycin ethylsuccinate & 6.47 \\
Erythromycin stearate & 6.86 \\
Roxithromycin & 5.94 \\
\hline
\end{tabular}

Table 3: Calibration parameters for the studied drugs

\begin{tabular}{||c|c|c|c|c|c|c|c|}
\hline Drug & $\begin{array}{c}\text { Calibration } \\
\text { Range }^{*} \\
\left(\mu \mathrm{g} \mathrm{ml}^{-1}\right)\end{array}$ & $\begin{array}{c}\text { intercept } \\
\mathrm{x} 10^{2}\end{array}$ & $\begin{array}{c}\text { Slope } \\
\mathrm{x} 10^{2}\end{array}$ & $\mathrm{r}$ & $\mathrm{r}^{2}$ & $\begin{array}{c}\text { LOD } \\
\left(\mu \mathrm{g} \mathrm{ml}^{-1}\right)\end{array}$ & $\begin{array}{c}\text { LOQ } \\
\left(\mu \mathrm{g} \mathrm{ml}^{-1}\right)\end{array}$ \\
\hline Azithromycin & $0.04-0.2$ & -0.20665 & 10.58940 & 0.9990 & 0.9980 & 0.0114 & 0.0380 \\
\hline Clarithromycin & $0.4-6.4$ & 0.304326 & 0.27882 & 0.9974 & 0.9948 & 0.5099 & 1.6995 \\
\hline $\begin{array}{c}\text { Erythromycin } \\
\text { Ethylsuccinate }\end{array}$ & $4-16$ & -0.17102 & 0.18463 & 0.9973 & 0.9946 & 1.7370 & 5.7900 \\
\hline $\begin{array}{c}\text { Erythromycin } \\
\text { stearate }\end{array}$ & $1.6-12$ & 0.74966 & 0.18809 & 0.9994 & 0.9988 & 0.5145 & 1.7200 \\
\hline \begin{tabular}{c} 
Roxithromycin \\
\hline
\end{tabular} & $0.4-4.0$ & 0.195200 & 0.33364 & 0.9992 & 0.9984 & 0.3260 & 1.0880 \\
\hline
\end{tabular}

Average of 3 determinations.

Table 4: Analysis of laboratory prepared mixture of erythromycin ethylsuccinate $\left(8 \mu \mathrm{gml}^{-1}\right)$ and sulfisoxazole acetyl in varying proportions $(\mathrm{n}=3)$.

\begin{tabular}{|c|c|}
\hline Added sulfisoxazole acetyl & $\begin{array}{c}\text { \% Recovery } \pm \text { SD of } \\
\text { erythromycin ethylsuccinate }\end{array}$ \\
\hline No addition & $98.88 \pm 1.15$ \\
$8 \mu \mathrm{g} \mathrm{ml}^{-1}$ & $98.50 \pm 1.65$ \\
$16 \mu \mathrm{g} \mathrm{ml}^{-1}$ & $99.37 \pm 1.70$ \\
$24 \mu \mathrm{g} \cdot \mathrm{ml}^{-1}$ & $97.37 \pm 1.31$ \\
\hline
\end{tabular}


Table 5: Analysis of Macrolide derivatives in commercial dosage forms by the proposed colorimetric and reported methods*.

\begin{tabular}{|c|c|c|c|c|c|}
\hline Dosage form & Drug & $\begin{array}{l}\text { Claimed } \\
\text { (mg) }\end{array}$ & $\begin{array}{l}\text { Found } \\
(\% \pm \mathrm{SD} \\
\text { Dosage form } \\
(50 \mathrm{mg})\end{array}$ & $\begin{array}{l}\text { Standard Add } \\
\text { method } \\
(25 \mathrm{mg})\end{array}$ & $\begin{array}{c}\text { Reported } \\
\operatorname{method}^{* *}(\% \pm S D)\end{array}$ \\
\hline $\begin{array}{l}\text { Erythrocin } \\
\text { tablets }\end{array}$ & $\begin{array}{l}\text { Erythromycin } \\
\text { (as stearate) }\end{array}$ & $500 /$ tab & $\begin{array}{l}97.50 \pm 1.12 \\
F=1.36, t=1.76\end{array}$ & $99.38 \pm 1.83$ & $98.66 \pm 0.96$ \\
\hline $\begin{array}{c}\text { Erythroprim } \\
\text { Tablets }\end{array}$ & $\begin{array}{l}\text { Erythromycin } \\
\text { (as stearate) }\end{array}$ & $250 /$ tab & $\begin{array}{l}95.92 \pm 1.44 \\
F=1.65, t=0.46\end{array}$ & $100.12 \pm 1.77$ & $96.4 \pm 1.85$ \\
\hline Klacid tablets & Clarithromycin & $250 /$ tab & $\begin{array}{l}95.85 \pm 1.06 \\
F=1.87, t=0.90\end{array}$ & $99.46 \pm 1.23$ & $95.12 \pm 1.45$ \\
\hline Xithrone tablets & Azithromycin & $500 /$ tab & $\begin{array}{l}98.35 \pm 1.05 \\
F=1.06, t=0.79\end{array}$ & $100.54 \pm 1.39$ & $98.88 \pm 1.08$ \\
\hline Roxid tablets & Roxithromycin & $300 /$ tab & $\begin{array}{l}98.06 \pm 1.10 \\
F=1.42, t=0.6\end{array}$ & $98.96 \pm 1.61$ & $97.60 \pm 1.31$ \\
\hline $\begin{array}{l}\text { Primomycin } \\
\text { capsules }\end{array}$ & $\begin{array}{l}\text { (Erythromycin) } \\
\text { as ethylsuccinate }\end{array}$ & 400/cap & $\begin{array}{l}98.66 \pm 1.34 \\
F=1.17, t=0.25\end{array}$ & $99.74 \pm 1.75$ & $98.44 \pm 1.45$ \\
\hline $\begin{array}{l}\text { Erythrocin } \\
\text { granule }\end{array}$ & $\begin{array}{l}\text { (Erythromycin) } \\
\text { as ethylsuccinate }\end{array}$ & 200/teasp & $\begin{array}{l}100.20 \pm 1.57 \\
F=1.04, t=0.6\end{array}$ & $99.66 \pm 1.84$ & $99.6 \pm 1.60$ \\
\hline $\begin{array}{c}\text { Primomycin } \\
\text { Oral suspension }\end{array}$ & $\begin{array}{c}\text { (Erythromycin) } \\
\text { as ethylsuccinate }\end{array}$ & 200/teasp & $\begin{array}{l}95.84 \pm 1.43 \\
\mathrm{~F}=1.25, \mathrm{t}=1.11\end{array}$ & $99.56 \pm 1.20$ & $96.90 \pm 1.60$ \\
\hline $\begin{array}{c}\text { Xithrone oral } \\
\text { suspension }\end{array}$ & Azithromycin & 200/teasp & $\begin{array}{l}94.74 \pm 1.17 \\
\mathrm{~F}=1.64, \mathrm{t}=1.04\end{array}$ & $98.48 \pm 0.88$ & $95.62 \pm 1.50$ \\
\hline
\end{tabular}

* Average of 5 determinations, Theoretical $\mathrm{F}$ and $\mathrm{t}$ values at $95 \%$ confidence limit are $\mathrm{t}=2.78$ and $\mathrm{F}=6.39$

** Reference number 5 using malonic acid-acetic anhydride method 
Table 6: Influence of small variations in the assay conditions on analytical performance of the proposed method for the determination of the macrolide antibiotics derivatives.

\begin{tabular}{|c|c|c|c|c|c|}
\hline \multirow[b]{2}{*}{ Variation } & \multicolumn{5}{|c|}{ Recovery $\% \pm \mathrm{SD}(\mathrm{n}=3)$} \\
\hline & $\begin{array}{l}\text { Azithromycin } \\
\left(0.12 \mu . \mathrm{ml}^{-1}\right) \\
\end{array}$ & $\begin{array}{l}\text { Clarithromycin } \\
\left(4 \mu \mathrm{g} \cdot \mathrm{ml}^{-1}\right)\end{array}$ & $\begin{array}{l}\text { Erythromycin } \\
\text { ethyl Succinate } \\
\left(8 \mu \mathrm{g} \cdot \mathrm{ml}^{-1}\right) \\
\end{array}$ & $\begin{array}{c}\text { Erythromycin } \\
\text { stearate } \\
\left(6 \mu \mathrm{g} \cdot \mathrm{ml}^{-1}\right) \\
\end{array}$ & $\begin{array}{r}\text { Roxithromycin } \\
\left(2.4 \mu \mathrm{g} \cdot \mathrm{ml}^{-1}\right) \\
\end{array}$ \\
\hline No variation & $98.70 \pm 1.61$ & $99.63 \pm 1.90$ & $98.88 \pm 1.15$ & $99.73 \pm 1.66$ & $100.47 \pm 1.89$ \\
\hline $\begin{array}{l}\text { Volume }(\mathrm{ml}) \text { of } \\
\text { buffer } \pm 0.2 \mathrm{ml}\end{array}$ & $100.33 \pm .16$ & $100.10 \pm 1.31$ & $99.13 \pm 1.37$ & $99.47 \pm 1.27$ & $99.80 \pm 0.92$ \\
\hline $\begin{array}{r}\mathrm{pH} \text { of buffer } \\
\pm 0.2 \text { unit }\end{array}$ & $98.80 \pm 1.25$ & $98.63 \pm 1.70$ & $98.27 \pm 1.13$ & $100.10 \pm 1.45$ & $98.07 \pm 1.29$ \\
\hline $\begin{array}{r}\text { Volume }(\mathrm{ml}) \text { of } \\
\text { dye } \pm 0.2 \mathrm{ml}\end{array}$ & $100.63 \pm .70$ & $99.50 \pm 1.78$ & $99.60 \pm 1.55$ & $99.30 \pm 1.30$ & $100.73 \pm 1.46$ \\
\hline
\end{tabular}

\section{Conclusion}

A validated, simple, sensitive, precise and specific spectrofluorimetric method is described for the determination of semi synthetic macrolide derivatives in bulk drug, tablets, capsule and oral suspension. No such need for releasing free erythromycin base which required long incubation period before analysis. ${ }^{10}$ The proposed method is of a great value in quality control determination of the studied antibiotics because of its simplicity, adequate accuracy; and reliability for the assay of these drugs in their pharmaceutical dosage forms without interference from common encountered excipients, other active ingredient such as trimethoprim, and sulfisoxazole acetyl. Besides, it is of low cost, since there is no need for expensive and/or sophisticated instruments and critical analytical reagent(s).

\section{REFERENCES}

1- S.C. Sweetman, Ed., "Martindale The complete Drug Reference", $33^{\text {ed }}$ Pharmaceutical Press, Press, London, UK, 2002, pp. 153, 186-187, 201, 247.

2- I. I. Hamadan, and A. M. Mishal, Saudi Pharm. J., 4, 191 (2000).

3- C. S. P. Sastry, D. S. Rao, and K. R. Strinivas, Indian Drug, 38, 594 (1998).

4- C. S. P. Sastry, K. P. Rao, and D. S. Parasad, Mikrochim. Acta, 122, 53 (1996).

5- N. N. A. Mohammed, Master Thesis "Analysis of Certain Antibiotics In Pure And Pharmaceutical Preparations", Department of Pharmaceutical Analytical Chemistry, Faculty of Pharmacy, Assiut Univ., Assiut, Egypt, 2004, pp. 165-204.

6- R. V. Smith, R. G. Harris, E. Sanchez, D.D. Maness, and A. 
Martin, Microchem. J. 22, 168 (1977).

7- A. Regosz, D. Dabrowska, and M. Leman, Sci. Pharm., 54, 23 (1986).

8- D. Dabrowska, A. Regosz, R. Pikos, M. Mierzawa, and B. Paruch, Microchem. J. 41, 210 (1990).

9- P. K. Khashaba, J. Pharm. Biomed. Anal. 27, 923 (2000).

10- A. Sanz, V. Tomas, C. MartinezLozano and T. Perez-Ruiz, Analyst, 118, 567 (1993).

11- K. Y. Tserng, and J.G. Wagner, Anal. Chem. 48, 348 (1976).

12- N. D. Danielson, L. He, J.B. Noffsinger, and L. Trelli, J. Pharm. Biomed. Anal., 7, 1281 (1989).

13- O. A. M. Farghaly and N. A. L. Mohamed, Talanta, 62, 531 (2004).

14- B. Nigovic, and B. Simunic, J. Pharm. Biomed. Anal., 32, 197 (2003).

15- H. S. Wang, A. M. Zhang, H. Cui, and D. J. Liu, Microchem. J., 64, 67 (2000).

16- T. Turcinov, and S. Pepeljnjak, J. Pharm. Biomed. Anal., 17, 903 (1998).

17- A. R. Breier, C. V. Garacia, T. P. Oppe, M. Steppe, and E. E. Schapoval, ibid., 29, 957 (2002).

18- The United States Pharmacopoeia XXV, the National Formulary $20^{\text {th }}$ Ed., 2002, US Pharmacopoeial Convention, Rockville, MD., pp. 188-190, 431-433.
19- The European Pharmacopoeia, $4^{\text {th }}$ Ed., Council of Europe, 2002, p. 1868.

20- The British Pharmacopoeia Her Majesty's Stationary Office, London, UK, 1998, pp. 1145.

21- M. Qi, P. Wang, R. Cong, and J. Yang, J. Pharm. Biomed. Anal., 35, 1287 (2004).

22- P. Wang, M. Qi, and X. Jin, ibid., 39, 618 (2005).

23- H. Amini, and A. Abolhassan, J. Chromatogr. B, 817, 193 (2005).

24- Y. H. Kim, J.V. Pothuluri, and C. E. Cerniglia, J. Pharm. Biomed. Anal., 38, 390 (2005).

25- W. Xiao, B. Chen, S. Yao, and Z. Cheng, J. Chromatogr. B Analyt. Technol. Biomed. Life Sci., 817, 153 (2005).

26- A. khedr, and M. Sheha, J. Chromatogr. Sci., 41, 1 (2003).

27- L. Kanfer, M. F. Skinner, and R. B. Walker, J. Chromatogr. A, 812, 255 (1998).

28- M. Pesez and J. Bartos Eds., "Colorimetric and Fluorimetric Analysis of Organic Compounds and Drugs", Marcel Dekker, Inc, New York, 1974, p. 628.

29- D. T. Sawyer, W. R. Heinman, J. M. Beebe, "Chemistry Experiments for Instrumental Methods", John Wiley \& Sons, New York, 1984, pp. 205 - 207.

30- D. B. Gomis, E. F. Alonso, and A. Sanz-Medel, Talanta, 32, 915 (1985).

31- D. B. Gomis, E. F. Alonso, E. A. Garcia, and P. A. Abrodo, ibid., 36, 1237 (1989). 
32- M. E. El Kommos, G. A. Saleh, S. M. El-Gizawi, and M. A. Abou-Elwafa, ibid., 60, 1033 (2003).

33- J. N. Miller, Analyst, 116, 3 (1991).

34- G. J. Manius and K. Florey Eds., "Analytical Profiles of Drug Substances", Academic Press, New York 1978, Vol. 7, pp. 445475.
35- L A. Paquette Eds., "Principles of Modern Heterocyclic Chemistry" W. A. Benjamin, INC. London 1968, p. 185 . 